$$
\text { LA-UR }-98-10 \% 9
$$

\title{
BASELINE TRITIUM CONCENTRATIONS IN SOILS AND VEGETATION: THE TSHIREGE WOODLAND SITE AT TA-54
}

by

\author{
P.R. Fresquez
}

\begin{abstract}
In compliance with Department of Energy (DOE) Order 5400.1, a preoperational environmental survey was conducted for the Tshirege woodland site - an experimental area managed by the Earth and Environmental Science Group (EES-15)-where radioactive tritium $\left({ }^{3} \mathrm{H}\right)$ will be injected ten $\mathrm{cm}$ deep in and around the base of pinyon (Pinus edulis) and one-seeded juniper (Juniperus monosperma) trees during the summer of 1990 . The site is located at the lower end of Canada del Buey close to the intersection of Pajarito and State Road 4. Baseline values of ${ }^{3} \mathrm{H}$ were measured in soil and plant samples from five locations immediately surrounding the study area. Mean values of ${ }^{3} \mathrm{H}$ in soils collected from the 0-5 and $25-30 \mathrm{~cm}$ depths were $1.24( \pm 0.22)$ and $1.08( \pm 0.41) \mathrm{pCi} \mathrm{mL}^{-1}$, respectively. Pinyon needles averaged $1.68( \pm 0.18) \mathrm{pCi}^{\mathrm{mL}^{-1}}$ and blue grama grass (Bouteloua gracilis) averaged 1.16 $( \pm 0.95) \mathrm{pCi} \mathrm{mL}^{-1}$.
\end{abstract}

\section{INTRODUCTION}

A preoperational environmental survey is required by the Departmental of Energy (DOE) for all new facilities or operations that will process, release, or dispose of radioactive materials (DOE 1998). Radioactive tritium $\left({ }^{3} \mathrm{H}\right)$ will be employed in a field experiment conducted by the Earth and Environmental Science Group (EES-15) during the summer of 1990. Plans are to spike tritium $10 \mathrm{~cm}$ deep in and around the base of pinyon (Pinus edulis) and one-seeded juniper (Juniperus monosperma) tress for the purpose of tracing the movement of water; a process pertinent to issues in waste management (Breshears 1989). The study will require the injection of $1 \mathrm{mCi}(37 \mathrm{MBq})$

${ }^{3} \mathrm{H}$ (as tritiated water) per experimental plot. Up to 30 plots will be spiked during the 
study. Therefore, in accordance with DOE Order 5400.1 , a preoperational study was conducted at the proposed study site to establish baseline concentrations of ${ }^{3} \mathrm{H}$ in soils and plants prior to the commencement of the experiment. This paper reports those results.

\section{MATERIALS AND METHODS}

The Tshirege woodland study site is located within Los Alamos National Laboratory (LANL) Technical Area (TA) 54 close to the intersection of Pajarito Road and NM State Road 4 (Figure 1). The site is classified as a pinyon/one-seeded juniper/blue grama (Bouteloua gracilis) habitat type (Foxx and Bennett 1990). There are no endangered or threatened plant or animal species known to exist in the area. The area occurs on a Penistaja sandy loam soil which consists of deep, well-drained soils (Nyhan et al. 1978). Water erosion is low and annual precipitation amounts to nearly $45 \mathrm{~cm}$ (DOE 1979). Most of the precipitation (75\%) falls between May and October. The predominant wind directions at the Area $G$ meteorological tower are southwesterly during the day, and northwesterly during the night (ESG 1989).

On June 1, 1990 soil and plant samples were collected from five locations immediately surrounding the field study site. Soils were collected at the 0-5 and at the 25-30 cm depth with a $14 \times 5 \mathrm{~cm}$ stainless steel ring and bucket auger, respectively. Approximately 1200 to 1400 grams of pinyon needles and blue grama grass were also collected. Individual samples of soils and vegetation were placed into 1 quart glass jars and double bagged into Ziplock plastic containers to protect against moisture loss. The samples were placed into ice chests for transport to the laboratory and kept frozen until analysis. Samples were submitted to the Health and Environmental Chemistry Group (HSE-9) for the analysis of ${ }^{3} \mathrm{H}$. Tritium was reported as activity per unit volume of soil water. Detailed descriptions of quality assurance/quality control procedures applicable to the collection and chemical analysis of soil and vegetation samples can be found in Quality Assurance Projected Plans (ESG 1987) and in Gautier et al. (1987).

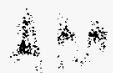




\section{DISCLAIMER}

This report was prepared as an account of work sponsored by an agency of the United States Government. Neither the United States Government nor any agency thereof, nor any of their employees, makes any warranty, express or implied, or assumes any legal liability or responsibility for the accuracy, completeness, or usefulness of any information, apparatus, product, or process disclosed, or represents that its use would not infringe privately owned rights. Reference herein to any specific commercial product, process, or service by trade name, trademark, manufacturer, or otherwise does not necessarily constitute or imply its endorsement, recommendation, or favoring by the United States Government or any agency thereof. The views and opinions of authors expressed herein do not necessarily state or reflect those of the United States Government or any agency thereof. 


\section{DISCLAIMER}

Portions of this document may be illegible in electronic image products. Images are produced from the best available original document. 


\section{RESULTS}

\subsection{Soils}

Tritium concentrations in soils collected at the $0-5 \mathrm{~cm}$ depth ranged from a low of 1.0 to a high of $1.6 \mathrm{pCi} \mathrm{mL}^{-1}$ (Table 1). Overall, mean soil concentrations of tritium at the $0-5 \mathrm{~cm}$ depth was $1.24( \pm 0.22) \mathrm{pCi} \mathrm{mL}^{-1}$. Long-term regional background data for tritium at the $0-5 \mathrm{~cm}$ depth has been reported to average around $2.6 \mathrm{pCi} \mathrm{mL}^{-1}$ (Purtymun et al. 1987). Tritium concentrations at the $25-30 \mathrm{~cm}$ depth averaged around $1.08( \pm 0.41)$ $\mathrm{pCi} \mathrm{mL}{ }^{-1}$. These soils ranged from 0.6 to $1.7 \mathrm{pCi} \mathrm{mL}^{-1}$ in tritium contents.

\subsection{Plant Materials}

Concentrations of tritium in vegetation are shown in Table 2. Pinyon ranged from 1.5 to $1.9 \mathrm{pCi} \mathrm{mL}^{-1}$ with an overall average of $1.68( \pm 0.18) \mathrm{pCi} \mathrm{mL}^{-1}$. Results from pinyon needles were very stable. Blue grama results, on the other hand, were more variable ranging from 0 to $2.2 \mathrm{pCi} \mathrm{mL}^{-1}$ with an average ${ }^{3} \mathrm{H}$ concentration of $1.16( \pm 0.95)$ $\mathrm{pCi} \mathrm{mL} L^{-1}$.

Table 1. Concentration of tritium $\left(\mathrm{pCi} \mathrm{mL}^{-1}\right)$ in soils collected at the 0-5 and the 25$30 \mathrm{~cm}$ depth from the Tshirege woodland study site on June 1, 1990.

\begin{tabular}{lll}
\hline & \multicolumn{3}{c}{ Depth (cm) } \\
\cline { 2 - 3 } Sample location & $\mathbf{0 - 5}$ & $\mathbf{2 5 - 0 3}$ \\
\hline$\# 1$ & 1.20 & 0.90 \\
$\# 2$ & 1.00 & 1.20 \\
$\# 3$ & 1.60 & 1.00 \\
$\# 4$ & 1.20 & 1.70 \\
$\# 5$ & 1.20 & 0.60 \\
Mean $( \pm$ std dev) & $1.24(0.22)$ & $1.08(0.41)$ \\
\hline
\end{tabular}

Table 2. Concentration of tritium $\left(\mathrm{pCi} \mathrm{mL}^{-1}\right)$ in pinyon and blue grama plant tissues growing within the Tshirege woodland study site on June $1,1990$.

\begin{tabular}{llc}
\hline Sample location & Pinyon & Blue grama \\
\hline$\# 1$ & 1.80 & 0.00 \\
$\# 2$ & 1.50 & 0.40 \\
$\# 3$ & 1.50 & 2.20 \\
$\# 4$ & 1.90 & 1.30 \\
$\# 5$ & 1.70 & 1.90 \\
Mean (土 std dev) & $1.68( \pm 0.18)$ & $1.16( \pm 0.95)$ \\
\hline
\end{tabular}




\subsection{References}

Brehears, D., "Action Description memorandum: Water and Nutrient Dynamics in a Pinyon/Juniper Community," Los Alamos National Laboratory ADM 89-11 (1989).

Department of Energy (DOE), "Final Environmental Impact Statement: Los Alamos National Laboratory Site," Los Alamos, New Mexico, DOE/EIS0018 (1979).

Department of Energy (DOE), U. S. Department of Energy Order 5400.1, General Environmental Protection Program (1988).

Environmental Surveillance Group (ESG), "Quality Assurance Project Plans, Environmental Surveillance Group, HSE-8," Los Alamos National Laboratory report LAUR-87-1076 (1987).

Environmental Surveillance Group (ESG), "Environmental Surveillance at Los Alamos During 1988," Los Alamos National Laboratory report LA-11628-ENV (1989).

Foxx, T.S., and K.D. Bennett, "Ecological Survey Report for the Proposed Location of the Meteorological (MET) Station," Los Alamos National Laboratory report, BIO-90-2 (1990).

Gautier, M.A., E.S. Gladney, W.D. Moss, M. Phillips, and B.T. O'Malley, "Quality Assurance for Health and Environmental Chemistry: 1986, Los Alamos National Laboratory report LA-1114-MS (1987).

Nyhan, J.W., L.W. Hacker, T.E. Calhoun, and D.L. Young, "Soil Survey of Los Alamos County, New Mexico, Laboratory report LA-679-MS (1978).

Purtymun, W.E., R.J. Peters, T.E. Buhl, M.N. Maes, and F.H. Brown, “Background Concentrations of Radionuclides in Soils and River Sediments in Northern New Mexico, 1974-1986," Los Alamos National Laboratory report LA-11134-MS (1987). 